\title{
Espaços para Crianças / Children's Spaces
}

https://doi.org/10.21814/uminho.ed.36.27

\section{Eunice Castro Seixas}

Centro de Sociologia Económica e das Organizações (SOCIUS), do Instituto Superior de Economia e Gestão (ISEG), Universidade de Lisboa 



\section{Espaços para Crianças ${ }^{5}$}

O conceito de "espaços para crianças" é ambíguo e controverso. A expressão tem sido frequentemente utilizada para se referir aos espaços que são considerados pelos adultos como sendo adequados para as crianças. Estes espaços têm sofrido modificações ao longo do tempo e à medida que emerge um reconhecimento da criança como ator social e sujeito de direitos, mas variam, também, segundo a cultura, etnia, ou a classe social, ou ainda segundo o género e a idade da criança. A demarcação destes espaços específicos para as crianças representa uma tendência da urbanidade moderna para a especialização e diferenciação, contribuindo para materializar e reproduzir determinadas conceções da infância, do espaço público e da "boa" parentalidade.

Mas a expressão "espaços para crianças" pode ser utilizada também para se referir aos espaços em que as crianças estão de alguma forma libertas do controlo dos adultos, ou ainda a espaços que são "construídos" ou apropriados pelas próprias crianças, e em que estas podem exercer a sua agência e participação, sendo que, nesta última aceção, é mais apropriado na língua portuguesa falar-se em "espaços das crianças".

A ambiguidade deste conceito remete, aliás, para o texto seminal de Kim Rasmussen (2004), sobre as discrepâncias entre os espaços que os adultos consideram serem para as crianças - "espaços para as crianças", tais como a escola e os parques infantis, e os espaços que estas apropriam como seus - "espaços das crianças". O trabalho de Rasmussen é paradigmático de uma perspetiva centrada nas crianças que realça a importância de uma análise a partir das experiências subjetivas e perceções das crianças. Simultaneamente, critica-se o modo como os espaços para as crianças têm sido planeados sem a participação das mesmas. Na mesma linha, vários autores têm denunciado e criticado a progressiva insularização, domesticação e institucionalização das crianças nas sociedades capitalistas ocidentais e

5 Este trabalho é financiado por fundos nacionais através da FCT - Fundação para a Ciência e a Tecnologia, I.P., no âmbito do Projecto PTDC/SOC-SOC/30415/2017.

This work was supported by FCT, I.P., the Portuguese national funding agency for science, research and technology, under the Project PTDC/SOC-SOC/30415/2017. 
suas consequências nefastas para a saúde, desenvolvimento e autonomia das mesmas, provocando simultaneamente um esvaziamento de crianças nos espaços públicos e a proliferação de espaços sem crianças.

Na realidade, estas discrepâncias entre espaços para as crianças e espaços das crianças são reveladoras das tensões que caracterizam os estudos participativos com crianças, designadamente: a tensão entre a participação como controlo social e a participação como emancipação; a tensão entre a criança como utilizadora de serviços e a criança como sujeito de direitos políticos e a tensão entre a proteção e o empoderamento das crianças (Shier, 2010). Estas tensões reproduzem as dicotomias da modernidade ocidental, nomeadamente a oposição entre a autorrealização e o controlo, através de uma limitação da agência das crianças no espaço público (Prout, 2000).

A própria ideia de demarcação de espaços infantis, ou seja, de criação de espaços exclusivamente para crianças, que separam as mesmas dos jovens e adultos, encontra sustentação teórica numa outra dicotomia moderna mais abrangente - o binário criança/adulto, e numa conceção tradicional do desenvolvimento como um processo linear, no sentido de uma progressiva complexidade e autonomia. Desde a emergência da nova Sociologia da Infância/das crianças nos anos 1980 que vários autores têm criticado esta conceção da infância como "ser em desenvolvimento" e salientado, em alternativa, a agência e a competência das crianças na negociação e transgressão das normas ditadas pelos adultos nestes espaços. A este respeito, autores como Kraftl ou Spyrou sugerem que a ideia de um espaço das crianças deve ser equacionada numa perspetiva relacional e depois intergeracional, uma vez que a agência das crianças é mediada pelos adultos e implica sempre uma relação de poder entre adultos e crianças. Neste sentido, mesmo os espaços sem crianças têm que ser compreendidos no contexto das relações culturais e intergeracionais.

Dentro das ciências sociais, a análise do modo como a criança se relaciona com o espaço tem implicado a mobilização de uma série de conceitos interrelacionados, embora oriundos de quadros teóricos e áreas disciplinares diversas, nomeadamente: a ligação ao lugar, o sentido de lugar, a apropriação do espaço ou ainda o conceito de "direitos socioespaciais". A sociologia tem-se aberto também progressivamente ao diálogo com outras ciências tais como a geografia, a psicologia ambiental, a antropologia ou a arquitetura. Nas últimas décadas, vários projetos interdisciplinares nas áreas do planeamento urbano participativo, ou do design participativo têm contribuído para uma desconstrução do mito de que a criança é incapaz de uma 
participação responsável, realista e crítica e revelado inúmeros benefícios, quer para as crianças, quer para a comunidade.

As perspetivas interseccionais e feministas, por sua vez, têm salientado para o modo como outros binários da modernidade ocidental, designadamente a oposição entre inocência e experiência, ou a dicotomia de género, continuam a marcar o modo como as crianças, e principalmente as crianças do sexo feminino e de grupos minoritários, são representadas socialmente e se relacionam com o espaço. No entanto, estudos recentes, influenciados pelas perspetivas feministas, estudos queer e teorias pós-coloniais, têm revelado também o modo como as crianças resistem a estas dicotomias, construindo identidades híbridas e complexas e exercendo a sua agência através de negociações contínuas entre transgressões e conformidade. Estes estudos revelam também a resistência do "Norte Global" em reconhecer e aceitar que existem diferentes concetualizações da infância e modos de relacionamento da criança com o espaço, assentes noutras realidades epistemológicas e socioculturais.

\section{Spaces for Children}

The concept of "spaces for children" is ambiguous and controversial. The term is often used to refer to spaces that are considered by adults as suitable for children. The planning of these spaces has changed over time, with the recognition of the child as a social actor and subject of rights, but these spaces also vary according to culture, ethnicity or social class, and according to the gender and age of the child. The demarcation of these specific spaces for children represents a tendency of modern urban planning towards specialization and differentiation, contributing to materializing and reproducing certain conceptions of childhood, public space and "good" parenting.

But the expression can also be used to refer to spaces where children are somehow free from adult control, or spaces that are "constructed" or appropriated by children themselves, and where they can exercise their agency and participation. In this sense, it is more appropriate in the English language, to speak of "children's spaces".

The ambiguity of this concept also relates to Kim Rasmussen's (2004) seminal text about the discrepancies between the spaces that adults consider to be for children - "spaces for children", - such as school and playgrounds, and the spaces that children appropriate as their own - "children's spaces". Rasmussen's work is paradigmatic of a child-centered perspective that 
builds from an understanding of the child's subjective experiences and perceptions. At the same time, it is a critique of the way in which spaces for children have been planned without their participation. Similarly, several authors have denounced and criticized the progressive insularization, domestication and institutionalization of children in Western capitalist societies, and the harmful consequences for their health, development and autonomy, leading to the loss of children in public spaces and the proliferation of spaces without them.

In fact, these discrepancies between spaces for children and children's spaces reveal the tensions that characterize participatory studies with children. There is the tension between participation as social control and participation as emancipation; the tension between conceptualizing the child as a service user and as the subject of political rights, and the tension between the protection and empowerment of children (Shier, 2010). These tensions reproduce the dichotomies of Western modernity, such as the dichotomy between self-realization and control, through a limitation of children's agency in public space (Prout, 2000).

The very idea of demarcating children's spaces, that is, creating spaces exclusively for children, which separate them from young people and adults, finds support in another broader modern dichotomy - the child/adult bina$r y$, and in a traditional conceptualization of development as a linear process towards progressive complexity and autonomy. With the emergence of the new sociology of childhood in the 1980s, several authors have criticized this conceptualization of childhood as "becoming" and stressed alternatively, the agency and competence of children in negotiating and transgressing the norms dictated by adults in these spaces. In this regard, authors like Kraftl ou Spyrou suggest that the idea of a children's space should be considered from a relational and intergenerational perspective, since children's agency is mediated by adults and always implies a power relationship between adults and children. In this sense, even spaces without children must be understood in the context of cultural and inter-generational relations.

Within the social sciences, the analysis of how children relate to space has implied the use of a series of interrelated concepts, though originating from diverse theoretical frameworks and disciplinary areas, namely place attachment, the sense of place, the appropriation of space or the concept of "socio-spatial rights". Sociology has also been progressively opening itself to dialogue with other sciences such as geography, environmental psychology, anthropology or architecture. Over the past decades, various interdisci- 
plinary projects in the areas of participatory urban planning or participatory design have contributed to a deconstruction of the myth that children are incapable of responsible, realistic and critical participation, and revealed numerous benefits for both children and the community.

Intersectionality and feminist perspectives, in turn, have drawn attention to the way in which other binaries of Western modernity, such as the dichotomy between innocence and experience, or the gender dichotomy, continue to influence the way children, and especially girls and children from minority groups, are socially represented and how they relate to space. However, some recent studies, influenced by feminist, queer and postcolonial theories, have also revealed how children resist these dichotomies by constructing hybrid and complex identities, and exercising their agency through ongoing negotiations between transgressions and compliance. These studies also highlight the resistance of the "Global North" in acknowledging and accepting that there are different childhood conceptualizations, as well as different ways in which children relate to space, based on different epistemological and sociocultural realities.

\section{Referências / References}

Prout, A. (2000). Children's participation: control and self-realisation in British late modernity. Children \& Society, 14(4), 304-315.

Rasmussen, K. (2004). Places for children - children's places. Childhood, 11(2), 155-173.

Shier, H. (2010). Children as public actors: Navigating the tensions. Children \& Society, 24(1), 24-37. 